\title{
Contra la guerra y el peronismo. Las imágenes de Ricardo Warecki en el diario Crónica de Rosario
}

\section{Artículo de Investigación}

\section{Elisabet Veliscek}

elisabet-veliscek@hotmail.com

Universidad Nacional de Rosario, Santa Fe, Argentina Consejo Nacional de Investigaciones Científicas y Técnicas, CONICET, Argentina

Recibido: 3 de abril de 2020

Aprobado: 10 de julio de 2020

Cómo citar este artículo: Veliscek, Elisabet (2021). Contra la guerra y el peronismo. Las imágenes de Ricardo Warecki en el diario Crónica de Rosario. Calle 14: revista de investigación en el campo del arte 16(29). pp. 128-145.

https://doi.org/10.14483/21450706.17408

\section{(a) (1)}

https://creativecommons.org/licenses/by/4.0/deed.es 

Contra la guerra y el peronismo. Las imágenes de Ricardo Warecki en el diario Crónica de Rosario

\begin{abstract}
Resumen
El artículo analiza las viñetas políticas, publicidades e ilustraciones del artista Ricardo Warecki en el diario Crónica de Rosario (Argentina) entre 1945 y 1947, en el contexto de los sucesos nacionales e internacionales que trajeron cambios económicos y políticos durante la segunda posguerra, el inicio de la guerra fría y el ascenso del peronismo. Las transformaciones sociales que se estaban produciendo en el mundo entero quedaron registradas bajo la mirada del artista de una manera satírica, y el humor gráfico fue utilizado como un modo de evidenciar su disconformidad ante el avance de la violencia y el autoritarismo.
\end{abstract}

\title{
Palabras clave
}

Argentina; arte moderno; guerra; gráfica; peronismo

Against the War and Peronism. The Images of Ricardo Warecki in the Journal Crónica of Rosario

\begin{abstract}
The article analyzes the political cartoons, advertisements and illustrations of artist Ricardo Warecki published by the newspaper Crónica de Rosario (Argentina) between 1945 and 1947, in the context of the national and international events that drove economic and political changes during the second postwar period, the beginning of the cold war and the rise of Peronism. The social transformations that were taking place around the world were registered by the satirical gaze of the artist, and graphic humor was used as a way to show his dissatisfaction with the advance of violence and authoritarianism.
\end{abstract}

\section{Keywords}

Argentina; modern Art; war; graphic arts; Peronism

Contre la guerre et le péronisme. Les images de Ricardo Warecki dans le Journal Crónica de Rosario

\section{Résumé}

L'article analyse les caricatures politiques, publicités et illustrations de l'artiste Ricardo Warecki publiées par le journal Crónica de Rosario (Argentine) entre 1945 et 1947, dans le contexte des événements nationaux et internationaux qui ont entraîné les changements économiques et politiques de la deuxième période d'après-guerre, le début de la guerre froide et la montée du péronisme. Les transformations sociales en cours dans le monde ont été enregistrées par le regard satirique de l'artiste, et l'humour graphique a été utilisé comme un moyen de montrer son mécontentement face à l'avancée de la violence et de l'autoritarisme.

\section{Mots clés}

Argentine ; art moderne ; guerre ; arts graphiques ; péronisme

Contra a guerra e o peronismo. As imagens de Ricardo Warecki no diário Crónica de Rosário.

\section{Resumo}

O artigo analisa as vinhetas políticas, publicidades e ilustrações do artista Ricardo Warecki no diário Crónica de Rosário (Argentina) entre 1945 e 1947, no contexto dos sucessos nacionais e internacionais que trouxeram mudanças econômicas e políticas durante a segunda pós-guerra, o início da guerra fria e a ascensão do peronismo. As transformações sociais que se estavam produzindo no mundo inteiro ficaram registradas sob o olhar deste artista de maneira satírica, e o humor gráfico foi utilizado como uma maneira de evidenciar sua inconformidade diante do avanço da violência e do autoritarismo. 


\section{Palavras chave}

Argentina; arte moderna; guerra; gráfica; peronismo

\section{llakiikunata ruraspa kawachilku Ricardo Warecki suti paipa kikaskapi}

\section{Maillallachiska}

Kai runa Ricardo Warecki parlaku pasaskata Argentina suti llagatapi kai watapi atun. Waranga iskun chuskupicka chunga kaura, chasallata atun waranga iskun chusku kanchis. Watapi kaikuna ruradur llapa iuillarispa kausachi imasami llapa llaki tia, chasallata ullarikuna chii nispa mana pudinchi utka ñugpasinama saruringa.

\section{Rimangapa ministidukuna}

Chasa suti Ilagata; kanauramanda rurai; Ilakiikuna; rurai; peronismo 


\section{Crónicas de actualidad}

A lo largo de las décadas de 1930 y 1940 Ricardo Warecki (Rosario, Argentina, 1911-1992) utilizó el humor gráfico en los medios de circulación periódica como un modo de manifestar sus opiniones respecto a la situación política. Era habitual que los artistas recurrieran a la prensa para traducir en imágenes hechos singulares que se producían en el escenario social y cultural argentino. Para eso se valían de la caricatura o las viñetas satíricas no solo como una forma de expresión humorística, sino también como un arma de combate y protesta frente a lo instituido. Sin embargo, estas imágenes estaban condicionadas por el contexto particular al que referían y el medio comunicacional en el cual se insertaban, por lo que adquirieron un carácter efímero en relación al resto de la producción plástica del artista. Debido a que generalmente Warecki no firmaba los escritos publicados en la prensa, conocer cuál era su punto de vista sobre determinados temas sociales se convirtió en un problema a franquear, más aún cuando otros pintores de la ciudad en ocasiones lo señalaran como alguien desinteresado o alejado del universo político. ${ }^{1}$ En este sentido, tanto los anuncios publicitarios como las caricaturas e historietas divulgadas en el diario Crónica de Rosario durante los años cuarenta iluminan una serie de cuestiones poco conocidas y de otro modo difíciles de percibir. Los episodios de la vida política contemporánea fueron motivo de comentarios incisivos interpretados visualmente con la incorporación de pequeños textos explicativos cargados de ironía. Esas ilustraciones dejaban en claro cuáles eran sus posturas en relación a los hechos internacionales y a los sucesos gubernamentales del ambiente nacional, pero al firmar con seudónimos evitaba en el momento posibles desavenencias o censuras.

A mediados de 1945, la conferencia de Potsdam y los posteriores ataques nucleares a Hiroshima y Nagasaki ordenados por Harry S. Truman que contribuyeron a la rendición de Japón y el final de la Segunda Guerra Mundial, así como los juicios de Núremberg y los enfrentamientos que iniciaron la Guerra Fría fueron algunos de los asuntos mundiales que preocuparon al pintor, mientras en el plano nacional el ascenso del

1 Por ejemplo, al referirse a los integrantes del Grupo Litoral, Juan Grela menciona: "Warecki no tenía posición política, venía del campo del dibujo publicitario". Si bien es cierto que el artista se había dedicado mayormente durante las décadas del treinta y del cuarenta a la ilustración, también había realizado algunas pinturas y enviado trabajos a los salones de Bellas Artes. El testimonio de Juan Grela fue recogido en Fantoni (1997, p. 53) peronismo identificado con una nueva forma de fascismo ocupó la mayor parte de sus viñetas dibujadas para "El plato del día". En esas imágenes el líder político era representado burlonamente como un militar caprichoso, inestable e ineficiente para gobernar. Al igual que en las imágenes realizadas una década antes para la revista Monos y Monadas (Veliscek, 2019a) se acentuaba la idea de farsa que caracterizaba a la política y sus hacedores, captando la tensión de cada momento histórico para satirizar la gravedad de los acontecimientos. Evidentemente, Warecki estaba interiorizado sobre lo que ocurría y tenía sus propias opiniones, aunque dichas ideas parecieran no haber traspasado nunca a la obra pictórica. Ese espacio de crítica y oposición lo encontró primero en el periodismo, lugar elegido por los artistas modernos de todo el mundo para captar los instantes de actualidad en un contexto de lucha por la libertad de expresión (Fisac Seco, 1999, p. 11) luego en su colaboración como dibujante en los boletines de la filial local de la Agrupación de Intelectuales, Artistas, Periodistas y Escritores (AIAPE); también en el diario Tribuna, órgano de difusión del Partido Demócrata Progresista y entre 1946 y 1950 a través de su participación en diferentes agrupaciones artísticas opositoras al gobierno de Perón como la Agrupación de Artistas Plásticos Independientes y el Grupo Litoral. ${ }^{2}$

A pesar del gran desarrollo que tuvo el humor político en la Argentina durante el transcurso del siglo $X X^{3}{ }^{3}$ al ser considerado un género menor y de una naturaleza fugaz, esos dibujos no eran a menudo valorados por los propios artistas, aunque funcionaron como instrumentos críticos y en ocasiones propagandísticos al servicio de una causa común o una militancia política. En ese marco, es posible mencionar otras publicaciones aliadas a la resistencia antifascista y antiperonista como Argentina Libre y Antinazi, con caricaturas de Clement Moreau, Toño Salazar y Tristán o Cascabel con dibujos de Landrú, Lino Palacio, Oski, entre otros. Los trabajos de estos dibujantes mantienen algunas coincidencias que pueden observarse también en las imágenes de Warecki, esto es, la crítica a la situación económica y el precio de los alimentos, el reparo ante la implementación de ciertas medidas como los planes quinquenales o la filiación del peronismo con formas del autoritarismo,

\footnotetext{
$2 \quad$ Si bien la Agrupación de Plásticos Independientes se creó en 1942, el artista recién comenzó a participar en 1946. En relación a las alternativas desarrolladas por estas agrupaciones en el marco de la Asociación Amigos del Arte, véase: Veliscek (2019b).

3 Diversos trabajos recopilaron a grandes rasgos la historia del humor gráfico y político. Señalamos, por ejemplo, los de: Vázquez Lucio (1985); Palacio (1993); Gociol y Rosemberg (2015).
} 
una asociación que se venía forjando entre los núcleos opositores desde hace tiempo atrás. Este posicionamiento del artista era compartido por el diario a través de algunas notas de 1946 alusivas a la declaración del 17 de octubre como feriado nacional en donde se alegaba que en el sistema democrático no debería existir "ni dictadura de la oligarquía ni dictadura del proletariado" y quien cargara con la responsabilidad de administrar el país debía hacerlo "respaldado por la mayoría, pero controlado por la minoría", respetando los derechos de todos los ciudadanos. ${ }^{4}$ La caracterización de la demagogia del gobernante y la tiranía que sometía los derechos fundamentales se convirtieron entonces en ideas comunes que aglutinaron a los artistas que suscribían a una perspectiva ligada a la vieja tradición liberal o a una izquierda más radicalizada. Es por eso que en el repertorio de viñetas políticas opositoras es común encontrar la identificación de Perón con un dictador nervioso e incapacitado políticamente, entretenido en su inocencia con la nacionalización ferroviaria y telefónica o los proyectos de monumentos a los "descamisados", como se observa en algunas imágenes de Warecki. Si bien el artista no llegó a recurrir a formas degradantes o sexistas, utilizaba la ironía con fines agresivos transformando lo cómico en una forma de ataque deliberado contra el sistema político y sus representantes.

Por otra parte, la colaboración del artista en el periódico se insertaba en el contexto de su participación en el Círculo de Prensa de Rosario, una institución que agremiaba a periodistas locales ${ }^{5}$ entre quienes se encontraban Angel Saggese y Mario Perazzi, los fundadores del diario Crónica, junto a Carlos Viana, a quien fue transferido el diario en mayo de 1946. Este último integraba también el Círculo de la Publicidad de Rosario y poseía la empresa Way Publicidad, donde Warecki trabajaba realizando anuncios publicitarios. A su vez, antes de tener una imprenta particular, el diario editó los primeros números en el taller de D. Miguel Pomponio, luego dirigidos por su hijo, Vicente Pomponio, quien tuvo a su cargo la impresión de varios libros y revistas ilustradas por Warecki. Las afinidades personales e ideológicas desarrolladas entre esos periodistas, impresores, trabajadores gráficos y dibujantes permitieron configurar un circuito en el que el artista se integró rápidamente. De hecho, en ese momento las agencias publicitarias de la Argentina solían contratar a periodistas como redactores y a artistas como diseñadores para encontrar las

$4 \quad$ Crónica (1946), Rosario, Argentina, 23 de octubre, p. 10.
5 Sobre el accionar del artista en este espacio véase: Veliscek
(2016/2017).

mejores ideas que pudieran servir para comunicar sus mensajes (Borrini, 1984, p.11). Como Warecki también se dedicaba a la crítica de arte y tenía conocimientos literarios es posible suponer que utilizara su talento en ambos sentidos. Debido a esos contactos generados con los medios de difusión masivos desde los inicios de su desarrollo artístico, era habitual encontrarlo en las fotografías que captaban las reuniones y celebraciones de diferentes entidades comerciales y culturales de la ciudad, posando al lado de escritores, periodistas y empresarios de la industria gráfica.

Asimismo, los periódicos y las revistas no sólo se encargaban de informar, también debían ser atractivos visualmente para captar la atención del comprador a través de tapas bien diseñadas e ilustraciones llamativas. En ese sentido, los anuncios propagandísticos muchas veces seguían el estilo general de la publicación tomando recursos de la historieta, el humor gráfico y la fotonovela o reproducían la tipografía y el sentido estético de sus páginas, como sucedía, por ejemplo, con las publicidades art decó de la revista Quid Novi?. Los artistas con experiencia en las estrategias publicitarias modernas y el diseño aplicado desempeñaban un papel central en esos medios y a diferencia de los dibujantes que, aun cuando formaran parte de alguna agencia, producían encargos de manera anónima, Warecki en ocasiones firmaba sus trabajos comerciales más importantes, aunque fuera con seudónimos. Esas intervenciones aparentemente superficiales en el universo publicitario se relacionaban y combinaban con su producción pictórica, generando una contaminación de expresiones visuales caracterizada por una influencia muy grande de la gráfica hacia la pintura.

\section{La ciudad industrial}

En 1940 el artista realizó carteles y publicidades gráficas para grandes tiendas departamentales como La Favorita, Gath \& Chaves; entidades crediticias y comerciales locales y en mayor cantidad para la Sociedad de Electricidad de Rosario, la primera empresa eléctrica de la ciudad perteneciente a una corporación belga, luego transferida a una compañía estatal. ${ }^{6}$ Algunas de esas

\footnotetext{
6 Como informa Norma Lanciotti, "En los años previos a la primera guerra mundial, y al cabo de una serie de fusiones y adquisiciones, el sector eléctrico pasó a ser controlado por empresas subsidiarias de compañías holding internacionales. Después de la guerra, la compañía holding belga Société Financière de Transports et d'Entreprises Industrielles (SOFINA) asumió el liderazgo del sector, controlando las empresas eléctricas más importantes del país; entre ellas, la
} 


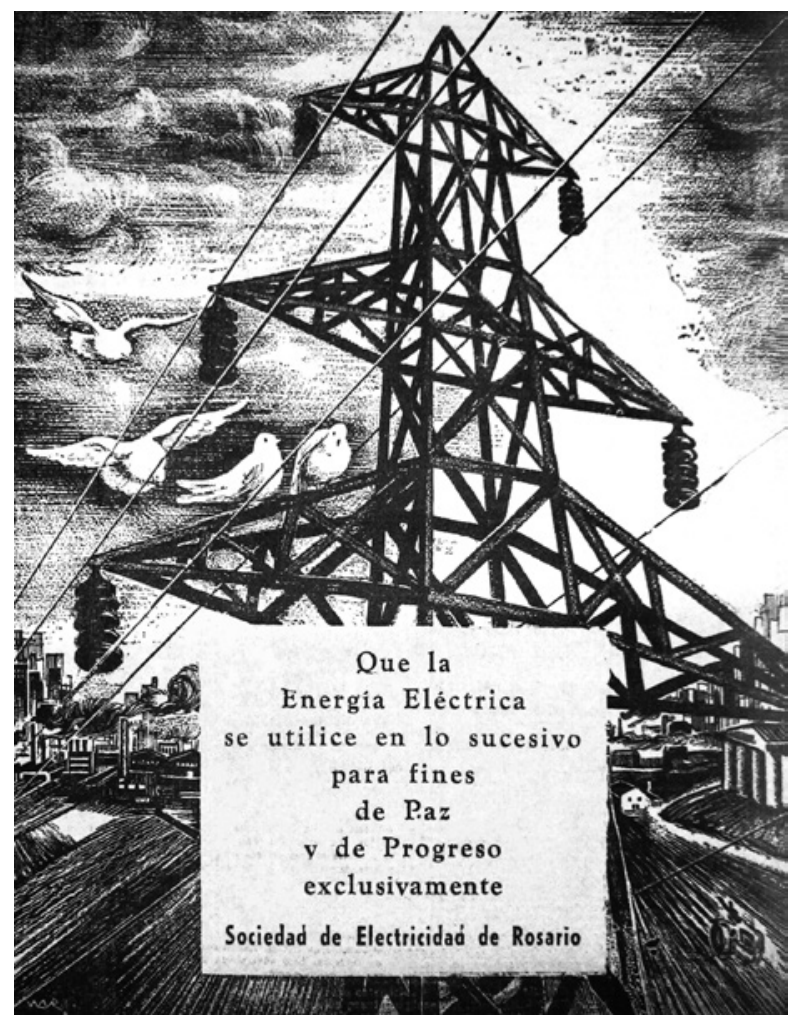

Imagen 1. Ricardo Warecki, publicidad para la Sociedad de Electricidad de Rosario, diario Crónica, Rosario, mayo de 1945.

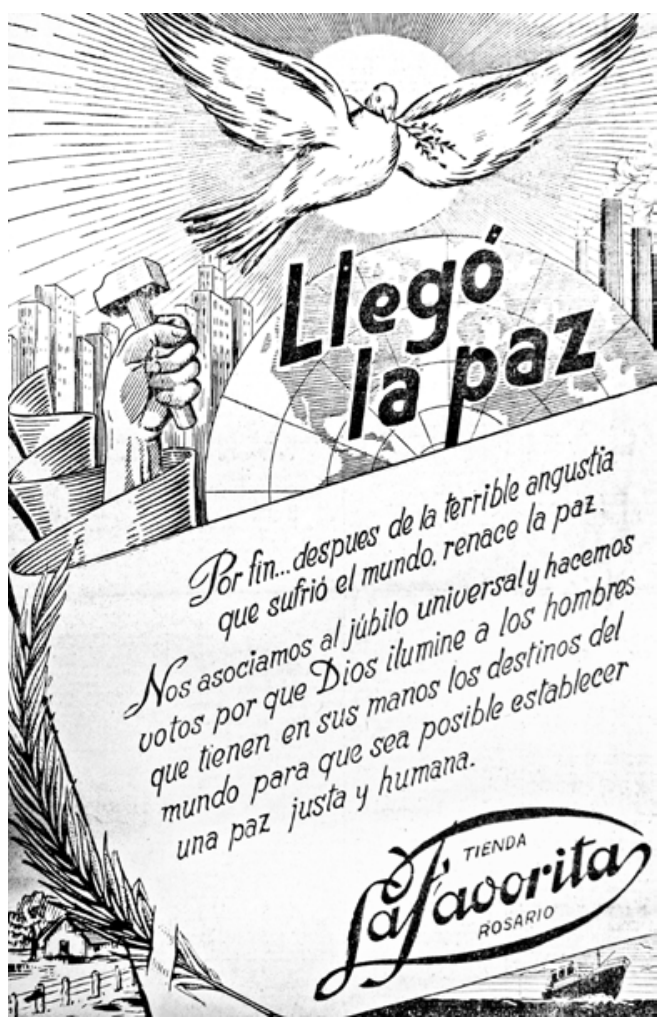

Imagen 2. Ricardo Warecki, publicidad para la Tienda La Favorita, diario Crónica, Rosario, mayo de 1945.

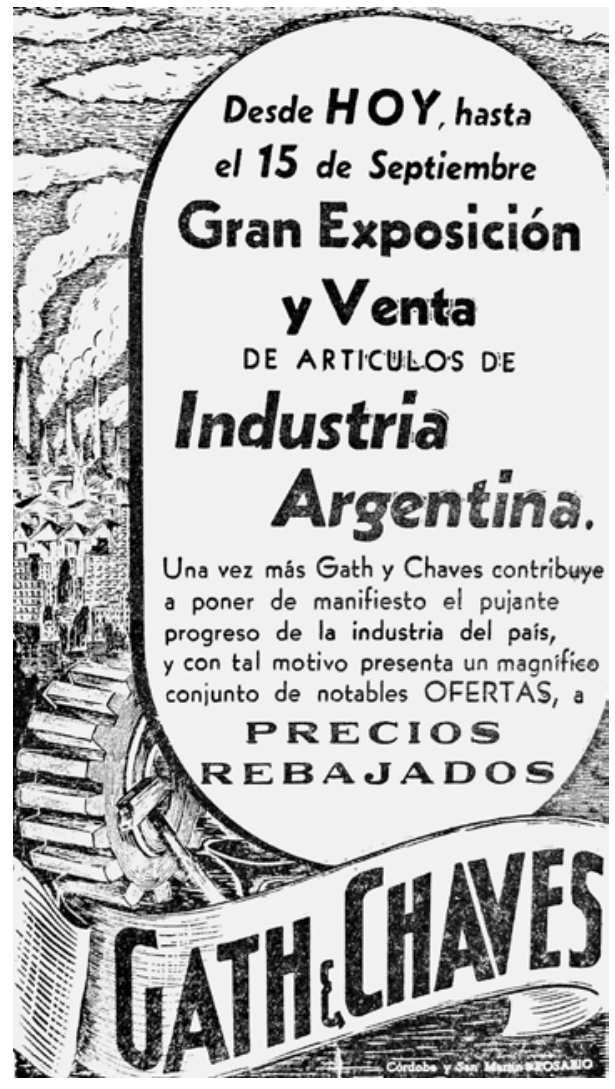

Imagen 3. Ricardo Warecki, publicidad para la Tienda Gath \& Chaves, diario Crónica, Rosario, septiembre de 1945 .

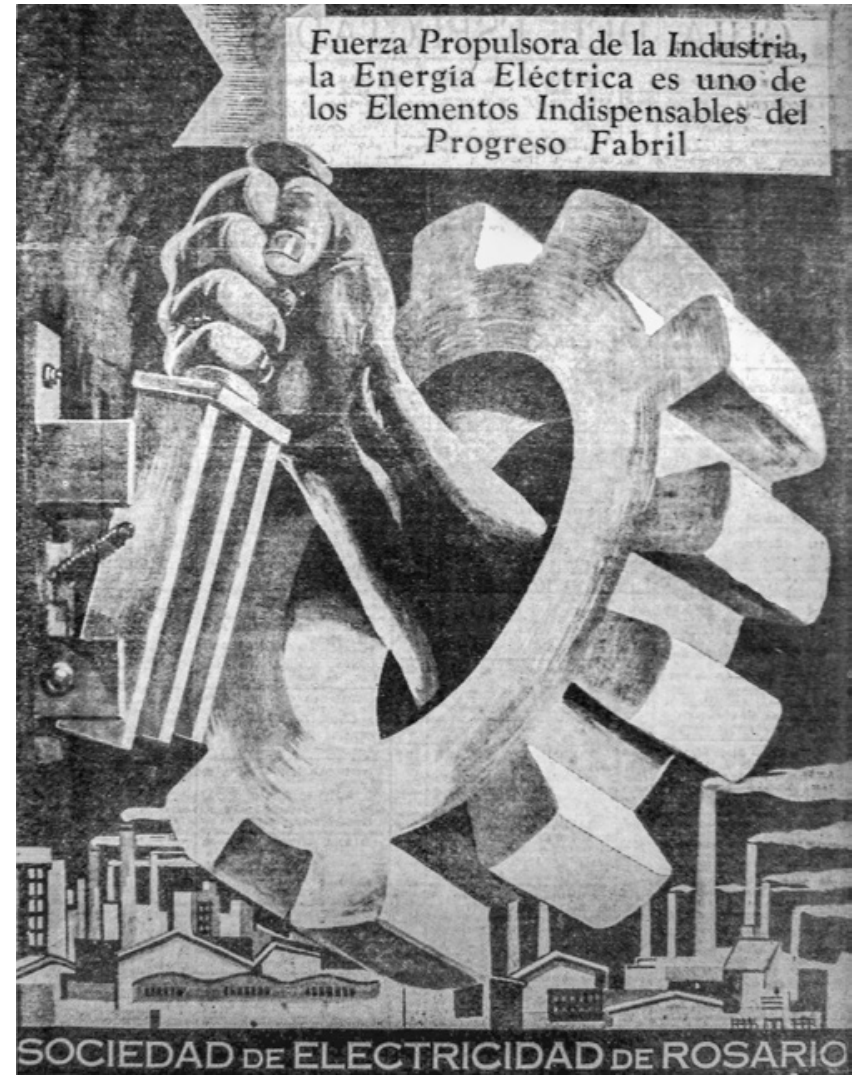

Imagen 4. Ricardo Warecki, publicidad para la Sociedad de Electricidad de Rosario, diario Crónica, Rosario, 27 de agosto de 1946. 
ilustraciones aparecieron en el diario y en gran medida hacían referencia al final de la Segunda Guerra Mundial y el desarrollo técnico, urbano e industrial de Rosario (Imágenes 1 a 4). Los conflictos desencadenados durante la segunda posguerra continuaron profundizando las tensiones internacionales del momento, por lo que durante ese periodo la propaganda de contenidos políticos y la publicidad comercial estuvieron estrechamente relacionadas en sus propuestas visuales. ${ }^{7}$ Entre algunos de los símbolos recurrentes de la iconografía política, la alusión a la paz mundial mediante el símbolo de la paloma blanca o del obrero en lucha con el puño levantado, se unieron en las imágenes propagandísticas del diario, a las representaciones maquinistas de engranajes mecánicos, chimeneas humeantes, torres eléctricas, galpones fabriles y edificios modernos para celebrar el final de la guerra y del crecimiento urbano e industrial. Esas imágenes estaban acompañadas por notas ensayísticas sobre las urgencias creadas por la destrucción agresiva que había arrasado con parte de la humanidad y de la cultura material. Así también, las ilustraciones incorporaban pequeños enunciados que complementaban los textos y daban sentido a las construcciones visuales.

En las imágenes realizadas para la Sociedad de Electricidad de Rosario, por ejemplo, una de ellas festejaba el término de la guerra mediante la representación de unas palomas blancas posando sobre postes de luz, símbolos de la electricidad moderna (Imagen 1). En las diferentes publicidades de la firma, la energía estaba ligada siempre al avance de la industria a partir de engranajes en movimiento, palancas que encienden aparatos, luces y faroles o máquinas y artefactos móviles. En esos dibujos el progreso técnico no se aproximaba a la poética luminista de los vanguardistas italianos, de manera que la luz no aparece como un efecto visual anunciando el sentido de la velocidad, sino como una manera de mostrar a la sociedad el modo en que los saberes sobre metalurgia, ingeniería y electricidad podían contribuir al desarrollo científico moderno. A su vez, como la empresa conocía los usos

Compañía Hispanoamericana de Electricidad (CHADE) y la Compañía Argentina de Electricidad (CADE) que operaban en Buenos Aires, y la Sociedad de Electricidad de Rosario (SER), en Rosario", en Lanciotti (2008, p. 90).

7 Durante el periodo de la posguerra española, al menos, "los anuncios y carteles comerciales fueron en muchas ocasiones simples derivados del cartel político". Sin embargo, debido a la coyuntura que atravesaba el país, en las publicidades también se infiltraron símbolos, lemas y estéticas asociadas al régimen franquista, cfr. Sueiro Seoane (2007, p. 14). destructivos que podían tener la máquina y la electricidad en tiempos de adversidad, la imagen contenía una inscripción sobre la utilización de la energía para fines pacíficos, y a través del diario sostenían la importancia de la preservación de la cultura a partir del auspicio de unos ciclos radiales de música clásica, transmitidos y seleccionados por la misma compañía. ${ }^{8}$

Otra publicidad de Warecki para la tienda La Favorita utilizaba la imagen de la paloma de la paz sosteniendo una ramita de olivo delante de un sol radiante que bañaba con su luz el cielo y todo a su alrededor (Imagen 2). En efecto, entre las representaciones visuales más difundidas sobre la electricidad estaban el rayo y el sol de la aurora, que retomaban imaginarios mitológicos y simbólicos asociados con el nacimiento de lo nuevo (Liernur y Silvestri, 1993, p. 14). El artista yuxtaponía a estas formas iconográficas una serie de elementos concernientes a la renovación técnica, empleando el recurso del montaje: junto a las chimeneas industriales y edificios de una fisonomía racional, que acompañaban el estilo de la arquitectura geométrica de finales de los treinta, aparece una embarcación atravesando el río Paraná, evocando los clásicos carteles de Cassandre para transatlánticos y locomotoras; el símbolo revolucionario del puño del obrero con el martillo, utilizado en ocasiones como insignia antifascista; una espiga de trigo, asociada por lo general con la abundancia de las cosechas, y una casa colonial en un entorno rural, en relación a aquellos espacios más apartados que no eran ajenos a los desarrollos de la modernización. Estos signos se reiteraban en otros anuncios en alusión a las destrezas manuales, que ocupaban un lugar significativo en los sectores medios como vía de ascenso social, ${ }^{9}$ y también en publicidades en donde prevalecía una mirada sobre la dimensión científica y profesional. En este sentido, pueden mencionarse otros diseños de Warecki realizados para la Sociedad de Electricidad de Rosario, publicados en distintos medios durante los años treinta y cuarenta, que exhiben científicos haciendo estudios en laboratorios, arquitectos

8 Un articulista del diario comentaba al respecto: "tratase
efectivamente de un ciclo de transmisiones (...) que se prolonga-
rá por mucho tiempo y conquistará sin duda alguna el favor de los
oyentes que hallarán en la transmisión de grandes composiciones
musicales, extranjeras o argentinas, la oportunidad de deleitarse a la
vez que instruirse. No vacilaremos pues en felicitar calurosamente a
la Sociedad de Electricidad de Rosario por su interesante y cultural
iniciativa". Véase: Programas artísticos auspiciados por la Sociedad de
Electricidad de Rosario. Crónica (1945), Rosario, Argentina, 25 de mayo.
$9 \quad$ Beatriz Sarlo exploró la ensoñación técnica analizando las
representaciones generadas durante los años veinte a través de la
literatura y la cultura popular. Sarlo, (2004 [1992]).


e ingenieros planeando grandes edificaciones urbanas u obreros de la construcción manipulando aparatos mecánicos. Además, la empresa realizaba homenajes a ingenieros eléctricos y científicos como una forma de acompañar los contenidos divulgados en los manuales y revistas masivas. Entre ellos, el diario publicó un retrato de Thomas Edison elaborado por Warecki a partir de una fotografía tomada por la empresa General Electric, para celebrar el centenario del nacimiento del famoso inventor (Imagen 5). Estas imágenes formaban parte de un plan de difusión ideado por la empresa en un momento conflictivo ocasionado por las gestiones del gobierno, comenzadas en 1946, para llevar a cabo la expropiación y nacionalización de la compañía, en el marco del programa de nacionalización de las empresas de servicios públicos (Lanciotti, 2008). Las acciones conducentes a la transferencia de corporaciones privadas a los poderes públicos suscitaron una serie de viñetas críticas del artista, difundidas en el diario. En una de ellas, unos peces de río se muestran cautelosos ante la carnada de un anzuelo que no tiene el letrero de "permiso nacional". ${ }^{10}$

El programa de estatización y formación de sociedades mixtas durante el peronismo proponía iniciar un nuevo ejemplo de organización centrado en la colaboración entre el empresariado y el Estado en la conducción de emprendimientos industriales y servicios públicos, o bien, en la administración total de empresas monopolizadas por capitales extranjeros (Belini, 2013). Sin embargo, esos proyectos levantaron controversias entre sectores políticos locales, que no consideraban la nacionalización una prioridad de Estado. La cartela que el artista incluyó debajo de la imagen, coincidía de forma burlona con las críticas de los círculos no partidarios:

Cuando los ríos provincianos sean nacionalizados, sólo habrá que esperar el estatuto de los pescados

Esa mirada satírica hacia las políticas sostenidas por el gobierno se complementaba con imágenes que aludían a las consecuencias inmediatas de la segunda posguerra, en contrapunto con las visiones utópicas sobre la transformación industrial y urbana producidas por la electrificación y el desarrollo de los saberes técnicos. En coincidencia con el estilo de las publicidades, en octubre de 1946 una noticia sobre los procesamientos de Núremberg fue motivo de una ilustración sobre las

10 Crónica (1946), Rosario, Argentina, 8 de octubre. ejecuciones de los criminales de guerra, en la que un cielo turbulento presagiaba las tormentas del mundo sobre los condenados a la horca (Imagen 6). No obstante, la aspereza inusual exhibida por Warecki en ese trabajo, las conmociones económicas y sociales provocadas por la contienda bélica, prolongadas por los conflictos subsiguientes entre los Estados Unidos y la Unión Soviética, así como la formación del peronismo y su caracterización como autoritarismo, quedarían registrados de modo sarcástico apelando al uso del chiste y la parodia. A través de dibujos asociados al estilo de los clásicos "cartoons" de prensa, estas pequeñas historias se inscribían en una tradición del periodismo gráfico que articulaba el humor con la política, los hechos parlamentarios y las críticas al sistema.

\section{Imágenes de la posguerra}

La gran devastación provocada por la guerra no solo implicó una oleada de muertes y destrucción masiva, también transformó las tensiones internacionales preexistente s en una confrontación entre dos superpotencias que intentaban forjar un nuevo orden acorde con sus objetivos e intereses particulares. En ese contexto, el incumplimiento de Stalin de las pautas establecidas en la conferencia de Yalta sumado al temor de los norteamericanos por la creciente popularidad de los partidos comunistas y el surgimiento en todo el mundo de grupos revolucionarios, anticolonialistas y antifascistas que podían aliarse a la Unión Soviética, entre otros factores, derivó en una serie de enfrentamientos ideológicos y geopolíticos que se fueron configurando y dilatando desde los últimos estadios de la Segunda Guerra Mundial (McMahon, 2009 [2003], pp. 53-54). Para afrontar esta amenaza latente, el presidente de los Estados Unidos, Harry S. Truman, implementó un conjunto de estrategias que respaldaran el desarrollo de una política exterior antisoviética y anticomunista, con el objetivo de frenar el avance de los movimientos revolucionarios. Debido a esos episodios, en octubre de 1946, Ricardo Warecki publicó una viñeta en alusión a la conferencia del primer ministro británico, Winston Churchill, en donde comunicaba, con el apoyo del presidente norteamericano, la formación de "un telón de acero" consistente en una frontera ideológica que dividiría Europa en dos bloques, el Occidental capitalista y el Oriental comunista, extendiéndose desde "Stettin en el Báltico hasta Trieste en el Adriático" (McMahon, p. 52). En la imagen (Imagen 7), los grandes líderes internacionales aparecen reunidos frente a un mapa divido por barreras territoriales e ideológicas, absorbidos por 


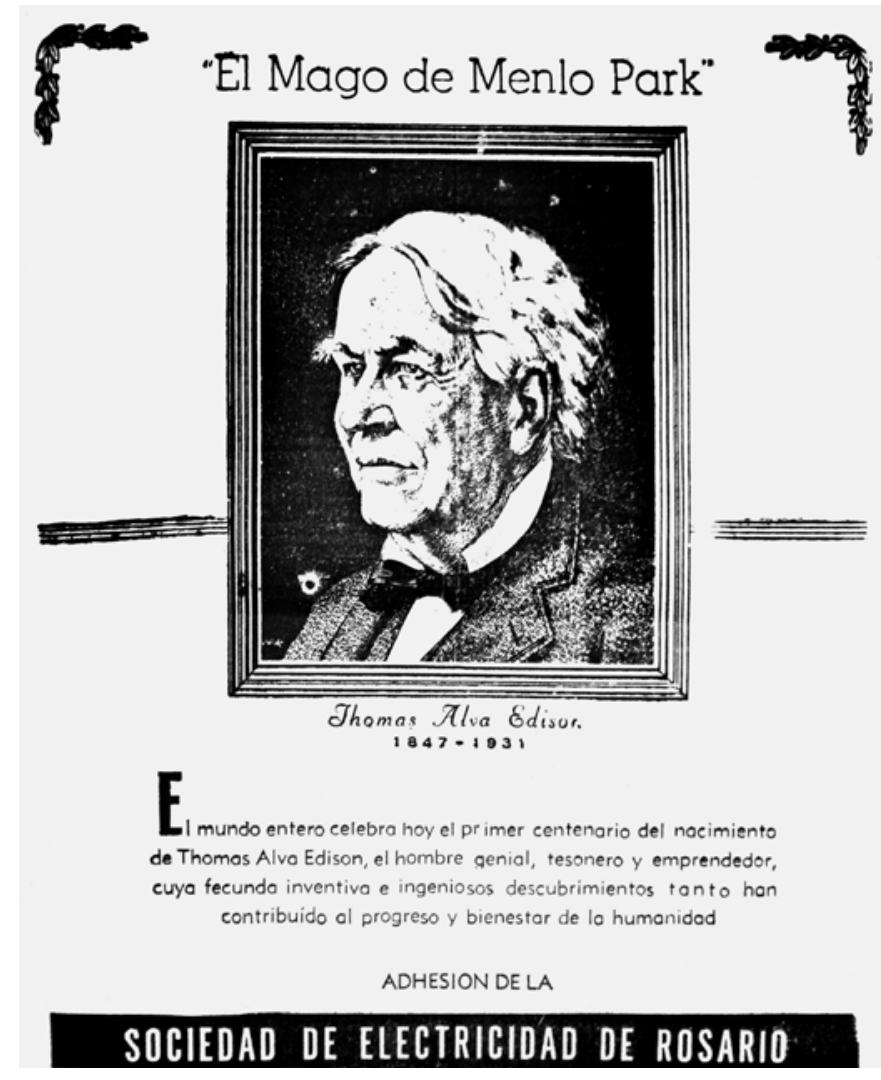

Imagen 5. Ricardo Warecki, publicidad para la Sociedad de

Electricidad de Rosario, diario Crónica, Rosario, 11 de febrero de 1947.

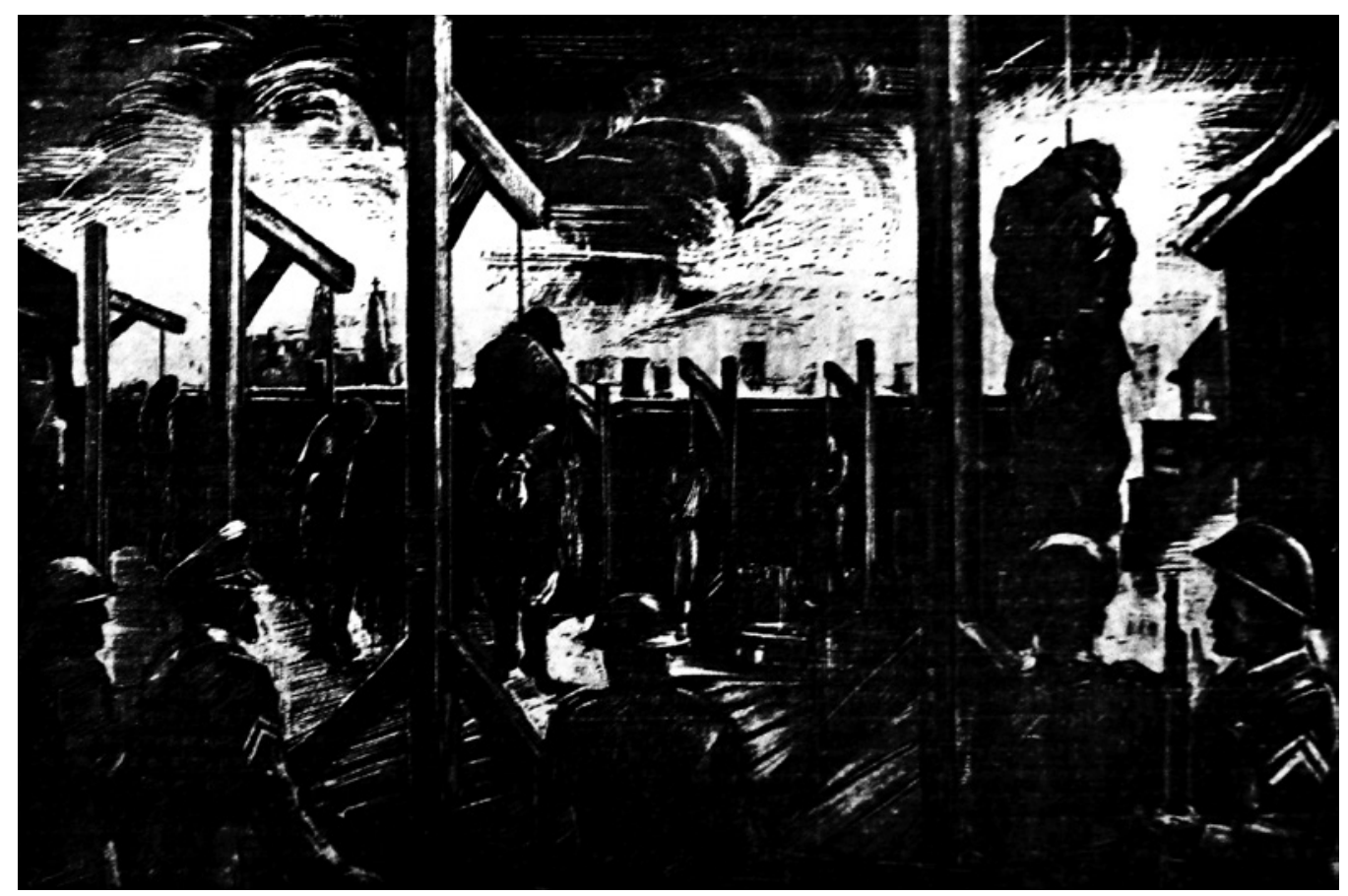

Imagen 6. Ricardo Warecki, ilustración para el diario Crónica, Rosario, 15 de octubre de 1946. 


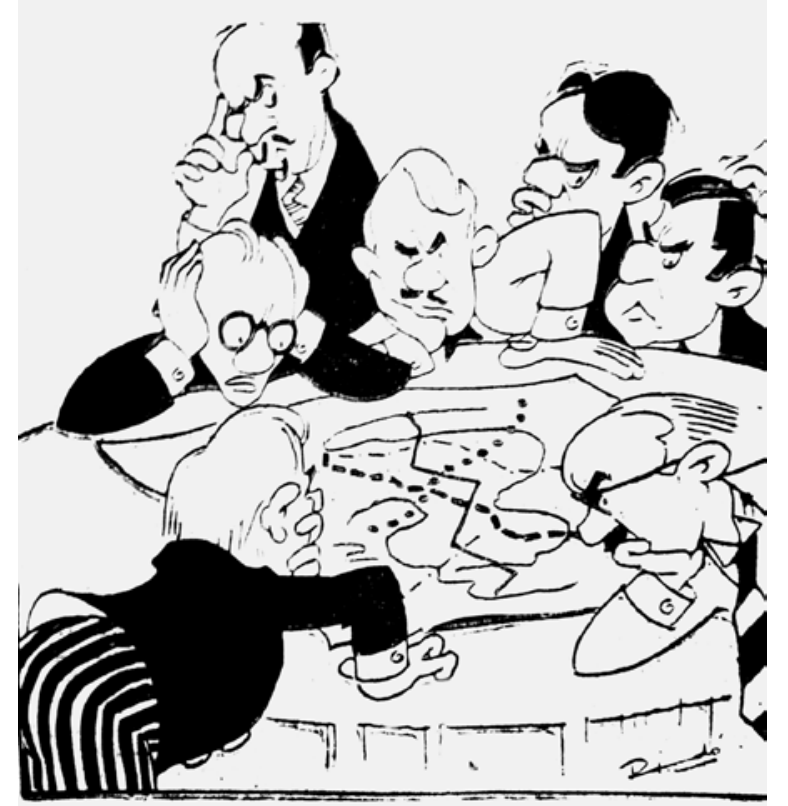

Al asunto de Trieste no lo encuentran la vuelte $y$ es tan dificultoso como un rompecabezas. ¿Descubrirán al cabo $y$ al Final do la cuenta que lo han escamoteado varias piezas?

Imagen 7. Ricardo Warecki, viñeta para el diario Crónica, Rosario, 1 de octubre de 1946.

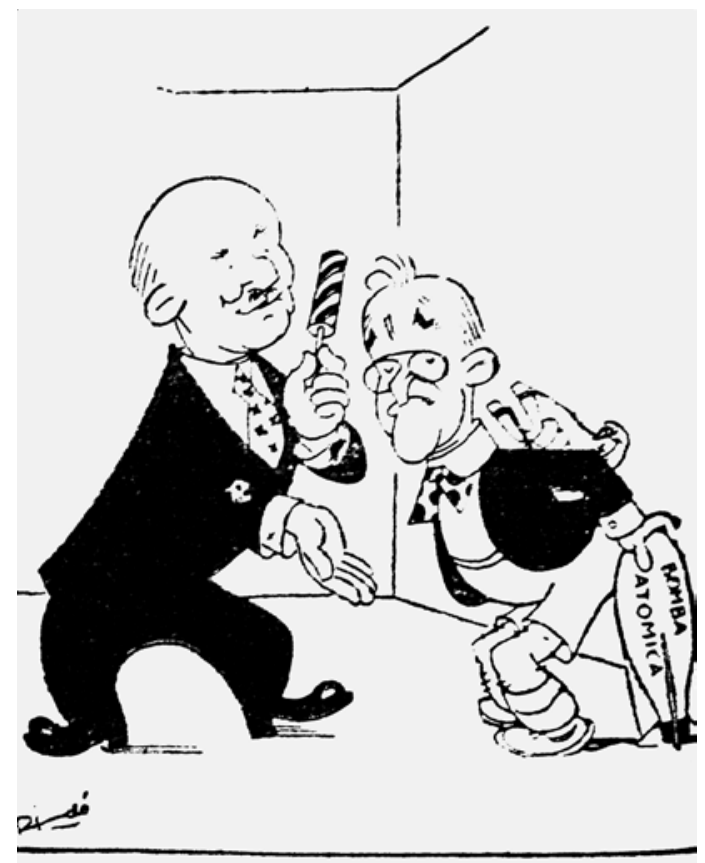

Como el chiche es peligros:

y $\delta$ puede lastimar,

Atlle, con mucha fireza,

se lo quiere hacer soltar

(Fero el nene es caprichoso

$y$ no se lo va a entregar).

Imagen 9. Ricardo Warecki, viñeta para el diario Crónica, Rosario, 7 de octubre de 1946.

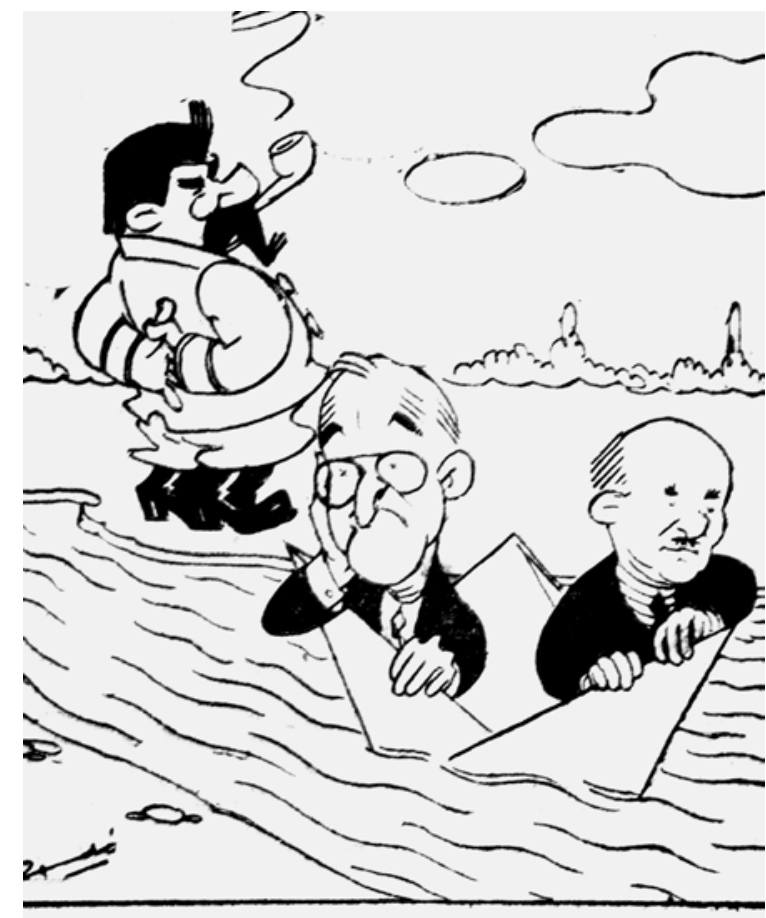

ATLEE. - Nos dejan navegar por el Danubio.

Es el paisaje encantador, ¿verdad?

TRUMAN - Cierto; pero está el río un poco turbio

y hay nubes que presagian tempestad.

Imagen 8. Ricardo Warecki, viñeta para el diario Crónica, Rosario, 2 de octubre de 1946.

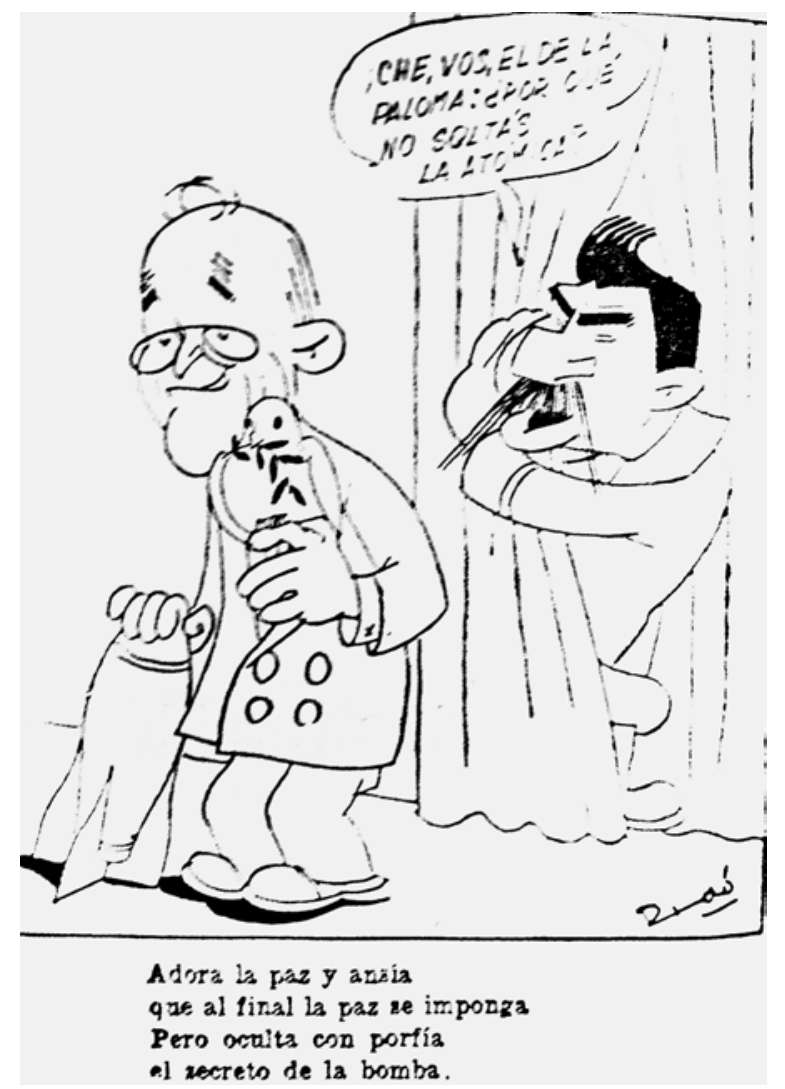

Imagen 10. Ricardo Warecki, viñeta para el diario Crónica, Rosario, 10 de octubre de 1946. 


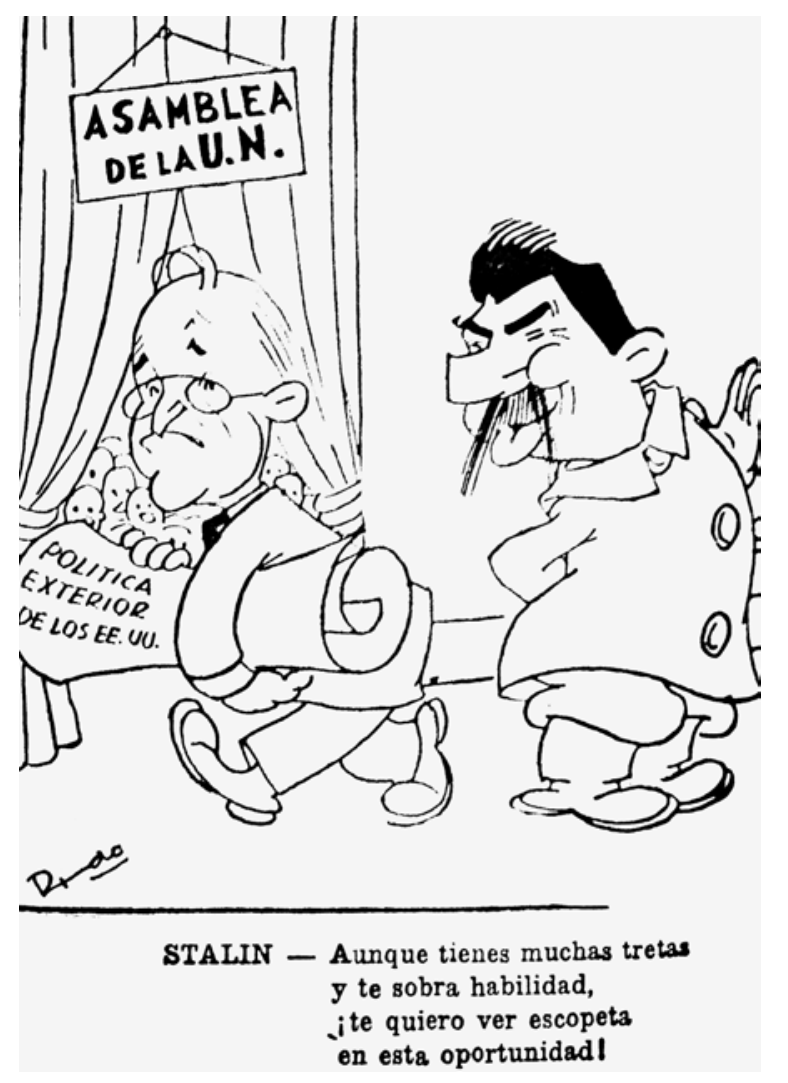

Imagen 11. Ricardo Warecki, viñeta para el diario Crónica, Rosario, 25 de octubre de 1946.

la preocupación de tener que resolver cómo afrontar los límites comerciales y políticos impuestos. Esas disputas inevitables quedarían evidenciadas en otra viñeta realizada poco después (Imagen 8), en donde el presidente norteamericano y el primer ministro británico navegan el Danubio en un barco de papel, mientras Stalin supervisa de cerca. A pesar de la tentativa de internacionalización del río como vía comercial de libre circulación, esa zona quedaría finalmente bajo el control de la URSS, por lo que el artista añade debajo una conversación entre Harry S. Truman y Clement Attle:

ATTLE: Nos dejan navegar el Danubio.

Es el paisaje encantador, ¿verdad?

TRUMAN: Cierto; pero está el río un poco turbio y hay nubes que presagian tempestad

Warecki aludía a la sombra amenazadora de una guerra que podría, otra vez, cernir el mundo en la oscuridad, si los desacuerdos entre estas dos potencias no se solucionaban de una manera pacífica. Pero no solo auguraba un porvenir incierto, también ironizaba sobre las relaciones manipuladoras sostenidas entre los Estados Unidos, la Unión Soviética y el Reino Unido para alcanzar el monopolio del armamento atómico y el

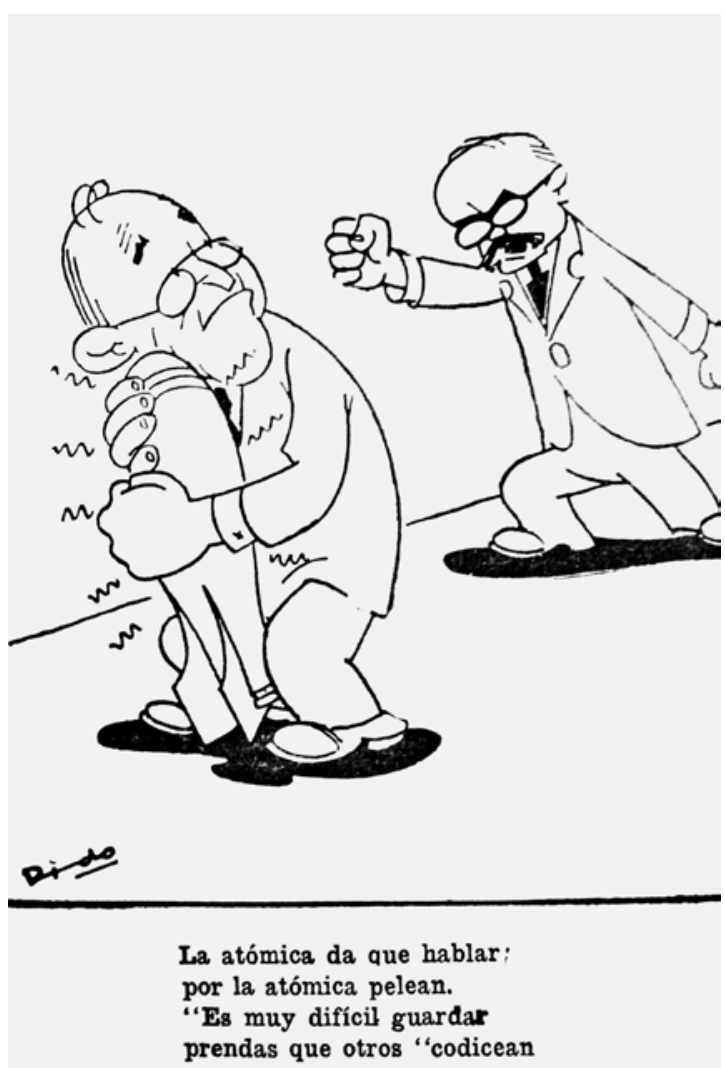

Imagen 12. Ricardo Warecki, viñeta para el diario Crónica, Rosario, 23 de octubre de 1946.

modo en que los bombardeos de Hiroshima y Nagasaki profundizaron las tensiones durante el primer periodo de la posguerra y la guerra fría (Imágenes 9 a 13). En este sentido, Truman aparece en las diferentes viñetas igualado a un niño rebelde con un juguete peligroso que no quiere prestar o a un hábil demagogo, justificando el uso de armas de destrucción masiva con el supuesto fin de doblegar a las potencias del Eje (Imágenes 10 y 11). De igual modo, el apoyo de la URSS a Palestina era representado como un esfuerzo diplomático para obtener el favor de las comunidades judías y liberar el Próximo Oriente del dominio británico (Imagen 14). En ambos sentidos, la política internacional era concebida por el artista como un espacio de pugnas ideológicas, conflictos territoriales y disputas económicas, manejado por un círculo hegemónico reducido que aparentemente debía encargarse de proteger los derechos fundamentales de la sociedad.

Ahora bien, el horizonte nacional tampoco parecía estar demasiado alejado de las luchas encarnizadas por el poder. Desde la década del treinta se habían organizado distintos grupos intelectuales y culturales de inclinación antifascista que después de las elecciones de febrero de 1946 devinieron en antiperonistas. 


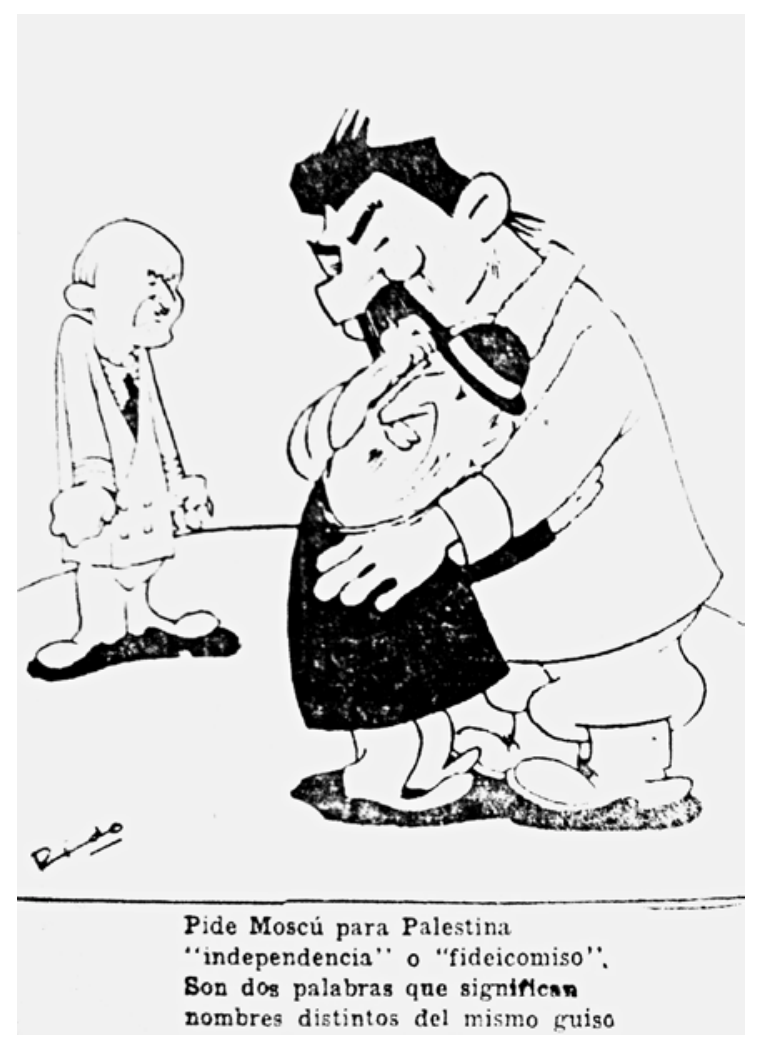

Imagen 13. Ricardo Warecki, viñeta para el diario Crónica, Rosario, 31 de octubre de 1946.

Ese núcleo opositor estaba conformado por un amplio espectro ideológico y político animado por diferencias fundamentales, pero que coincidían en el perfil totalitario de Perón. El giro autoritario del régimen militar de la segunda mitad de 1943 afianzó en gran medida la sensación entre los intelectuales de que se estaba formando un sistema de características fascistas, apoyado por grupos militares, nacionalistas y católicos. ${ }^{11}$

A través del humor gráfico publicado en el diario se puede observar con claridad, desde los primeros días de octubre de 1946, la asociación que el autor hace del peronismo con las dictaduras y fascismos europeos. El artista traduce visualmente sus opiniones respecto a la ineptitud del nuevo gobernante, a la vez que se encarga de marcar en todo momento la corrupción e ineficiencia del sistema político nacional y la vinculación de las medidas económicas implementadas por el peronismo con los procedimientos usados por los totalitarismos extranjeros. Una de las viñetas, por ejemplo, muestra cinco cubos apilados de manera inestable formando con sus letras la palabra "Perón", junto a un cartel de "prohibido tocar" (Imagen 15). Según el texto que

11 En relación a estos temas consultar el tomo de García Sebastiani (2006).

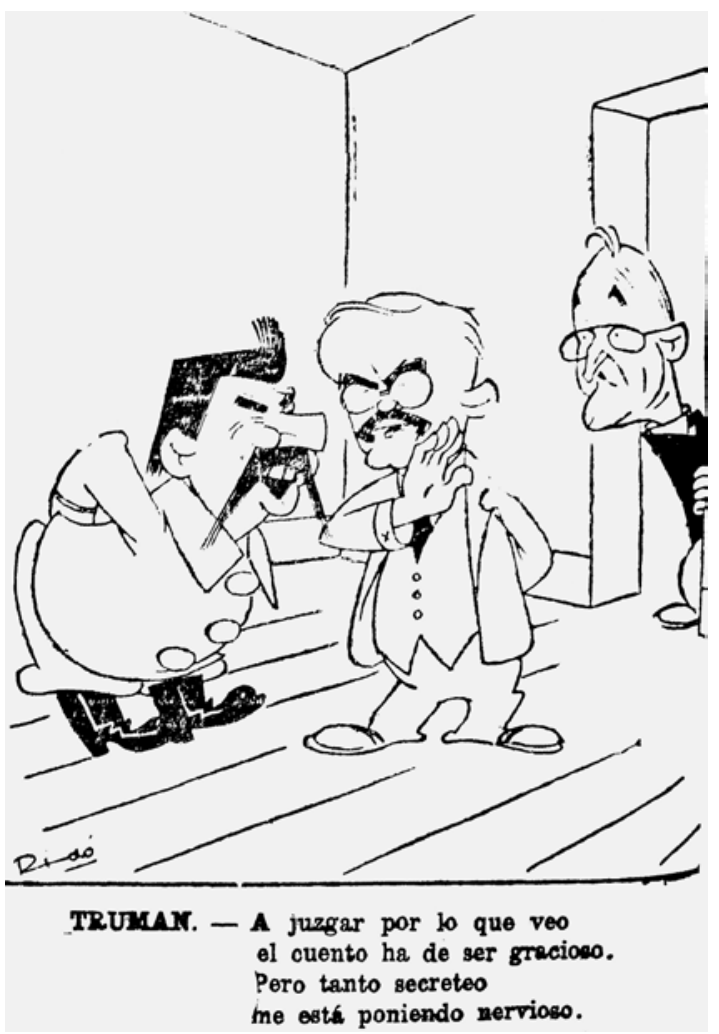

Imagen 14. Ricardo Warecki, viñeta para el diario Crónica, Rosario, 12 de noviembre de 1946.

acompaña la imagen, la fragilidad de los cubos era una referencia a la inutilidad del plan quinquenal que se había anunciado como un método de planificación en el segundo tramo de 1946. Esta analogía entre el régimen peronista y la dictadura estalinista formaba parte de otro dibujo donde el líder de la Unión Soviética sostiene un diario argentino y se pregunta por la familiaridad que le suscita este "nuevo" proyecto nacional (Imagen 16).

Por otro lado, el gobierno era descalificado por su fomento a los feriados nacionales, que en muchos casos no eran remunerados y terminaban afectando el salario de los trabajadores (Imagen 17); por la incoherencia de los programas económicos y el aumento excesivo de los productos de consumo diario (Imágenes 18 y 19) o por la desmedida atención puesta en proyectos que a simple vista parecían triviales (Imágenes 20 y 21). A partir de esto, el artista ponía en escena la ingenuidad peligrosa que a su entender caracterizaba al régimen, mediante una ilustración en la cual dos científicos proyectaban cálculos enrevesados sobre una pizarra para intentar "descubrir la fórmula del Único Partido de la Revolución", así llamado inicialmente el Partido Peronista (Imagen 20). Utilizando un diseño simple con trazos lineales en blanco y negro, propio de la gráfica política, a través de estas caricaturas el artista 


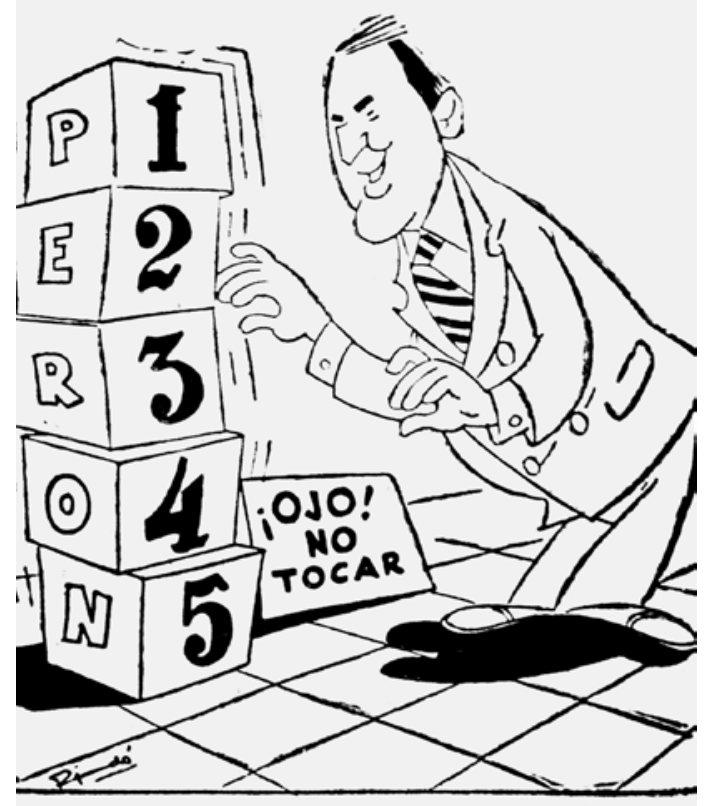

Es entretenimiento provechoso y tan original,

que puedo echar diez años o cincuenta este plan quinquenal.

Imagen 15. Ricardo Warecki, viñeta para el diario Crónica, Rosario, 5 de octubre de 1946.

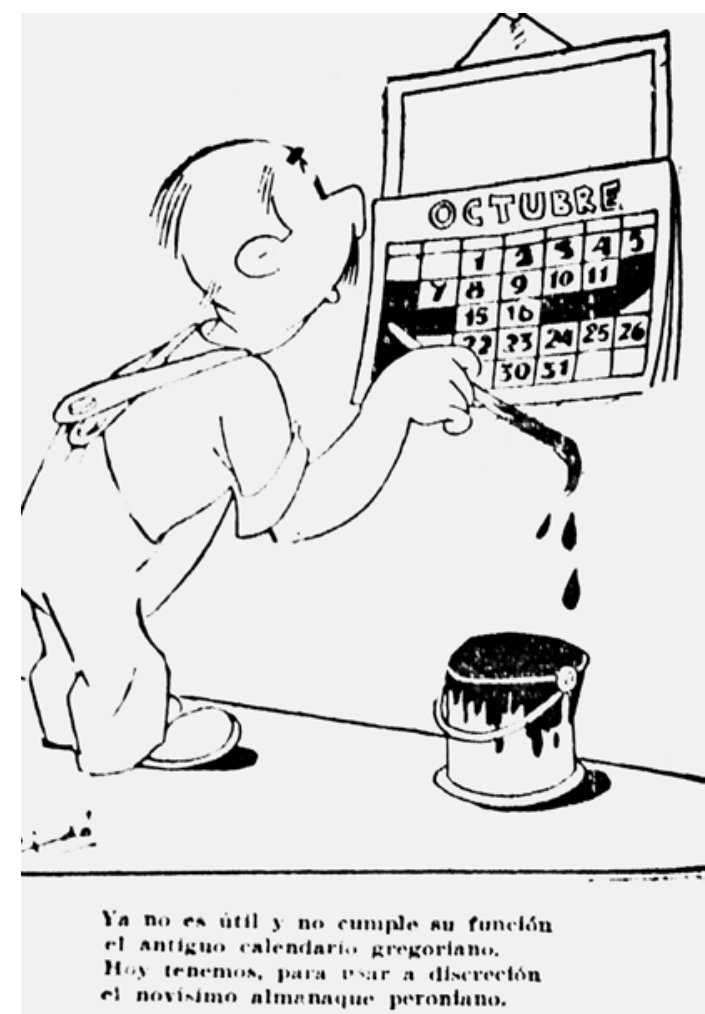

Imagen 17. Ricardo Warecki, viñeta para el diario Crónica, Rosario, 19 de octubre de 1946.

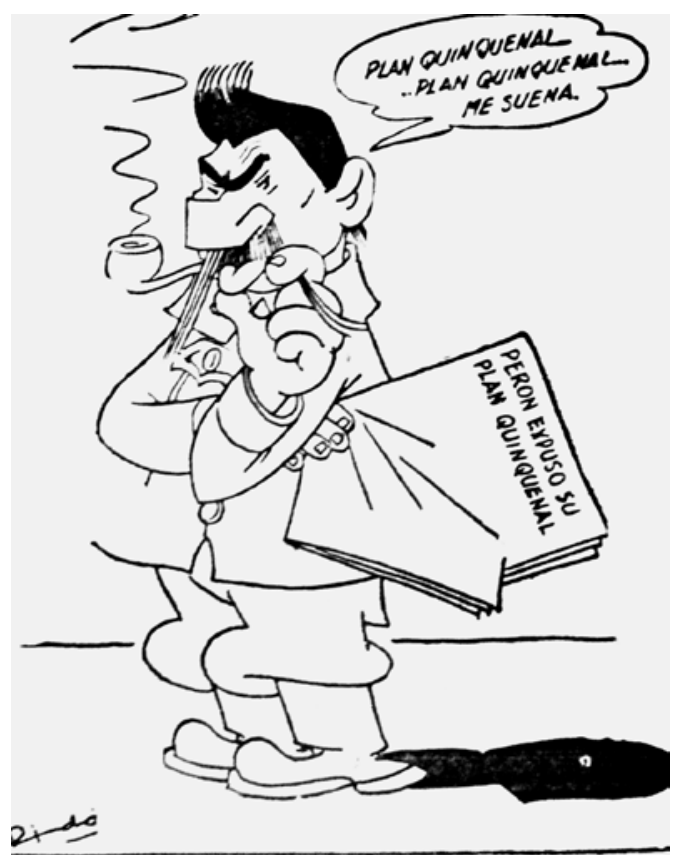

No obstante

que algunos duden que es original. adaptado a la vida nacional,

es importante

Este plan quinquenal.

Imagen 16. Ricardo Warecki, viñeta para el diario Crónica, Rosario, 22 de octubre de 1946.

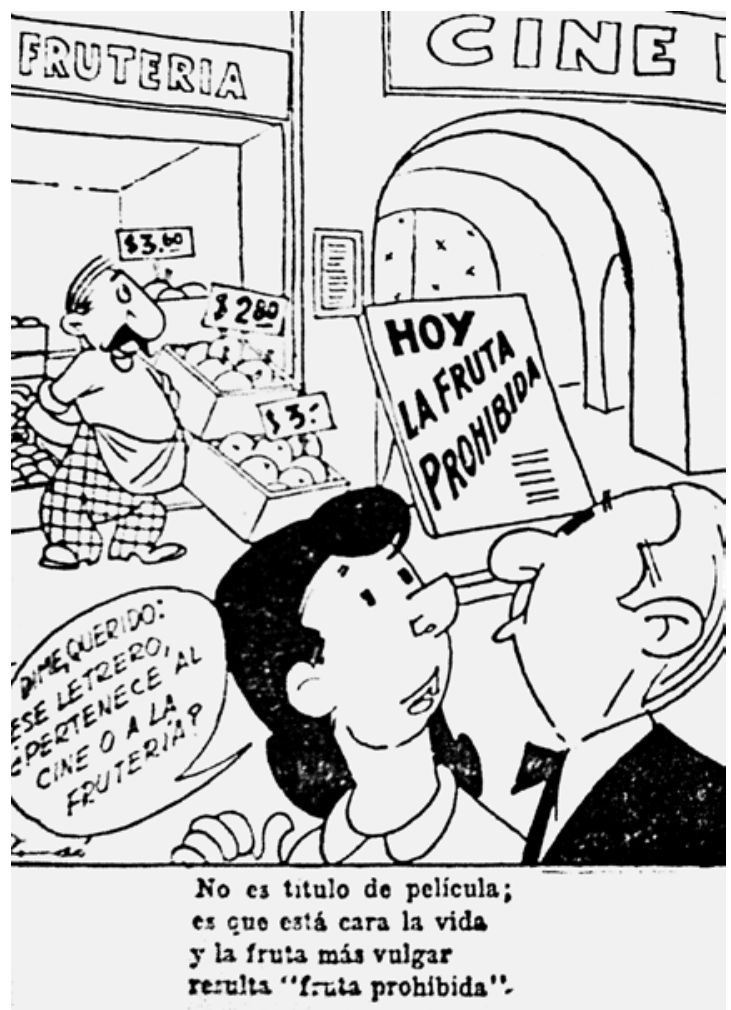

Imagen 18. Ricardo Warecki, viñeta para el diario Crónica, Rosario, 20 de noviembre de 1946. 


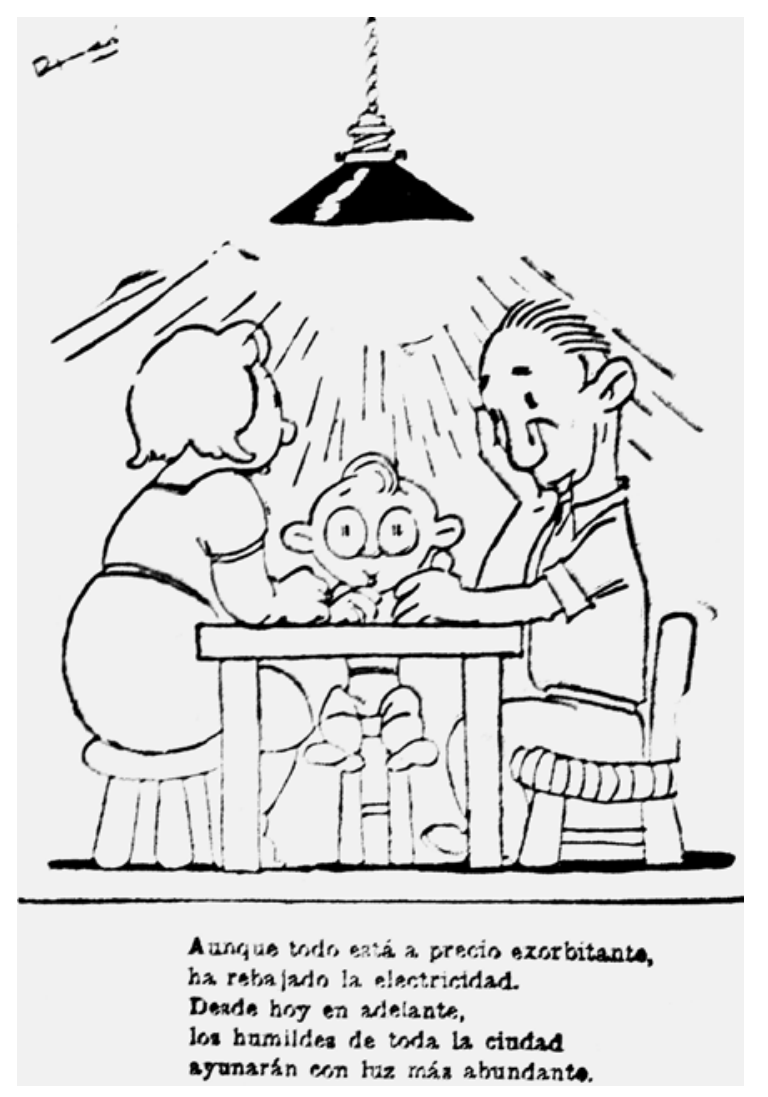

Imagen 19. Ricardo Warecki, viñeta para el diario Crónica, Rosario, 1 de noviembre de 1946.

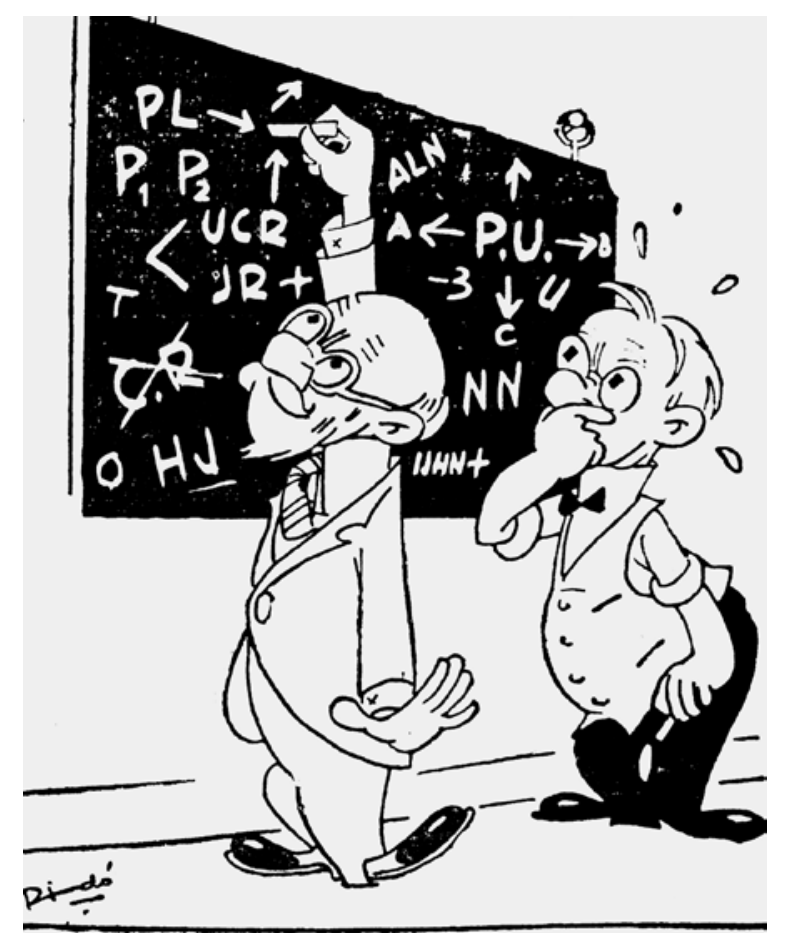

No son sesudos cálculos atómicos

Ni complejos teoremas de etérea dimensión

So trata simplemente de descubrir la fórmula

Del Unico Partido de la Revolución.

Imagen 20. Ricardo Warecki, viñeta para el diario Crónica, Rosario, 30 de noviembre de 1946.

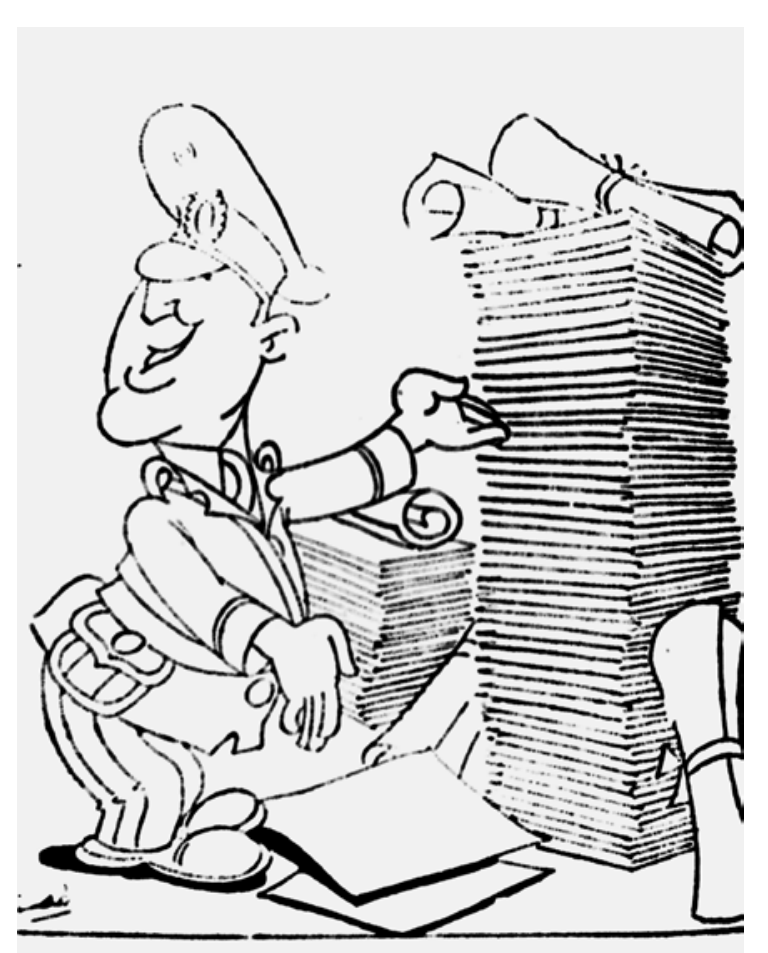

E. to que veis, por ciert.

no es el plan quinquenal, perded cuidado.

Ellos son, solamente, mis proyectos

del monumento a los descamisadis.
Imagen 21. Ricardo Warecki, viñeta para el diario

Crónica, Rosario, 21 de octubre de 1946. 
ridiculizaba al gobierno, pero sin caer en la típica demonización y criminalización que era posible ver en las historias y viñetas de las publicaciones antiperonistas del momento. ${ }^{12}$ Su producción gráfica era más bien una forma de resistencia personal frente a un adversario que consideraba intolerante, incompetente y no muy distinto de los líderes de aquellas potencias mundiales que podían causar estragos por un simple capricho.

\section{Los Salones del Trabajo}

No obstante, a pesar de haber manifestado su posicionamiento crítico a través de variadas imágenes, Ricardo Warecki sostuvo estratégicamente una participación en los Salones del Trabajo organizados por el Ministerio de Trabajo y Economía de la Provincia de Santa Fe. Estos salones fueron realizados entre el 30 de abril y el 17 de mayo de 1947 y 1948 en el Museo Municipal de Artes Visuales de Santa Fe, en el marco de la intervención peronista al Comisionado Municipal y del proyecto de intervención federal a la provincia. ${ }^{13}$

La participación en estas convocatorias oficiales se relaciona con una práctica de inserción plástica en la que, a menudo, aquellos artistas con una ideología opuesta al gobierno o a los sistemas de adjudicación de premios, optaban en algunos casos por enviar obras a los salones de bellas artes. Si bien algunos de ellos terminaran renunciando a los premios, realizando manifestaciones paralelas o manteniendo sus experimentaciones plásticas e ideas políticas en universos separados, la posibilidad de obtener una distinción significaba una vía de ascenso y reconocimiento casi inmediato. En este sentido, al mismo tiempo que el artista mandaba obras a los Salones del Trabajo, participaba en las últimas reuniones y declaraciones de la Agrupación de Artistas Plásticos Independientes de Rosario, un conjunto de pintores de tendencias antifascistas y antiperonistas que realizaban obras sin aparente contenido político, pero con una carga simbólica sugerente que podía interpretarse en función del momento singular que estaba atravesando el país.

Entre tanto, la mediación del gobierno quedaba claramente fijada a través de las resoluciones anunciadas para el Primer Salón, en donde se planteaba que las

\footnotetext{
12 Algunas de estas representaciones se encuentran en las páginas de la revista Antinazi, sucesora de Argentina Libre. Véase: Nállim (2014, pp. 195-243).

13 Fue presentado el proyecto de intervención amplia a Santa Fe. El Orden (1947), Santa Fe, Argentina, 12 abril, p. 1
}

obras (pintura, dibujo y grabado) debían exaltar el trabajo "como expresión dinámica del pueblo argentino", "ejemplo del sano ideal que labora el progreso material de la nación" y "como reconocimiento del esfuerzo diario de los trabajadores", para lo cual se designaba la fecha de apertura y permanencia de la exposición entre abril y mayo de cada año, en homenaje al día de los trabajadores. Siguiendo la retórica de la época, el texto redactado por el ministro Juan C. Apullán, continuaba:

Que el arte plástico, lenguaje de múltiples resonancias espirituales, es medio propicio para captar las escenas del trabajo y plasmar un vehículo expresivo de los afanes populares, en consonancia con el sentir de un pueblo que ha sabido imponer su voluntad de justicia social y de dignidad humana. ${ }^{14}$

Sobre estas premisas, algunas de las obras quedaban fuera de concurso si se apartaban levemente de los temas consignados en los instructivos generales, y en el primer salón esto sucedió con un porcentaje importante de pinturas, acuarelas, dibujos y grabados de artistas rosarinos y santafesinos que representaban pescadores, costureras, campesinos, leñadores, cortadores de paja, entre otras labores, al menos en los títulos, pero posiblemente en las imágenes estas figuras quedaran inmersas en el paisaje natural o en el intimismo del hogar.

En el caso de Ricardo Warecki, su primer envío consistió en una pintura titulada Construcción 1947 (Imagen 22) que, exhibiendo una temática americanista infrecuente en el resto de la producción del pintor, obtuvo el tercer premio adquisición del "Ministro de Hacienda y Obras Públicas". ${ }^{15}$ A pesar del mal estado de conservación en que se encuentra la obra en el museo y la oscuridad que ha adquirido el óleo con el paso del tiempo, es posible ver una composición en la que aparecen hombres y mujeres indígenas trabajando en una enorme construcción que se alza sobre el cielo, al lado de un edificio racionalista y cercana a un puente de vigas industriales. Esta iconografía se articula en cierto sentido con la pintura del General San Martín realizada a mediado de los años cuarenta para el Círculo de Prensa de Rosario, en donde aparecen indios y gauchos acompañando al libertador con su ejército. Continuando también con

\footnotetext{
14 Primer Salón del Trabajo. Pintura, dibujo y grabado (1947) 15 El primer premio quedó en manos de su compañero Carlos $\mathrm{E}$. Uriarte con una obra sobre los cosechadores de lino, y el segundo para una pintura dedicada a un obrero isleño del artista santafesino César López Claro. Montes i Bradley, Ricardo (1947) y Primer Salón de Trabajo, pintura, dibujo y grabado (1947)
} 


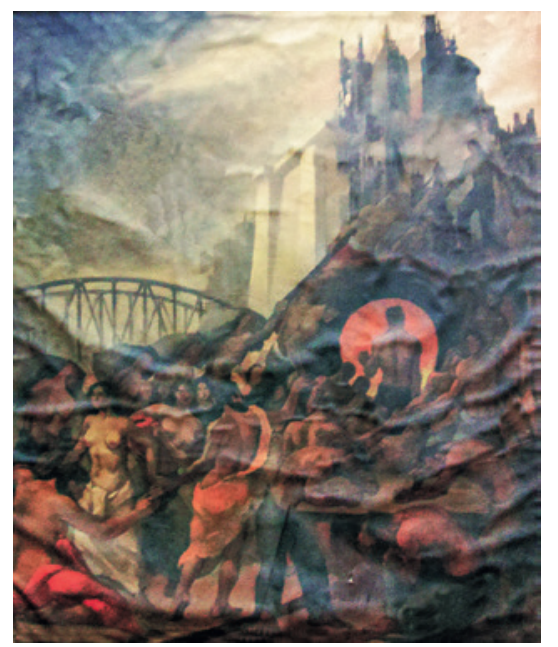

Imagen 22. Ricardo Warecki, Construcción 1947, óleo sobre tela, 109 × 93 cm, Museo Municipal de Artes Visuales "Sor Josefa Díaz y Clucellas", Santa Fe, Argentina.

estas temáticas, el artista presenta unos Campesinos en el Salón Nacional de ese mismo año y en 1948 vuelve a participar de los Salones del Trabajo con el óleo Segadores municipales, aunque sin recibir ningún premio en esa ocasión.

La intervención de Warecki en estos espacios permite trazar un terreno de contradicciones en donde vemos que su pensamiento estaba lejos de ser unilateral. El hecho de haber integrado el núcleo inicial de artistas plásticos abocados a la tarea de fundar una institución con el objetivo de fomentar el intercambio cultural argentino-norteamericano, también lo demuestra. Aunque la creación de ARICANA en 1943 se sustentaba en los ideales de democracia y libertad, dos años más tarde el artista tenía una visión muy distinta que no dudaba en expresar públicamente.

Al mismo tiempo, en el ámbito de las artes visuales los salones del peronismo habían manifestado un cambio radical respecto a los organizados en periodos anteriores. ${ }^{16}$ Sin embargo, como indica Giunta (1999), aunque se agregaran cláusulas especiales que privilegiaban determinados tópicos populares o se establecieran fechas relacionadas con el ascenso de Perón para la apertura del Salón, no hubo en general una política de exclusión violenta como ocurrió en otras partes del mundo. Los artistas disidentes siguieron enviando obras a los salones oficiales, en ocasiones con temáticas que podían parecer a simple vista elusivas, o se decantaron

16 Véase el completo trabajo sobre las transformaciones que afectaron a los salones nacionales de ese periodo en Giunta (1999, pp. 153-190). por manifestar sus posiciones de manera pública a través de la prensa, las agrupaciones artísticas alternativas y los salones independientes.

Los medios de difusión masivos le permitieron a Ricardo Warecki exponer a un público amplio sus intereses e ideas políticas sobre los hechos internacionales que mantenían en vilo al mundo entero, y también manifestar sus desavenencias con respecto a lo que consideraba el avance autoritario del nuevo gobierno nacional. Trabajar sobre papeles le ofrecía una libertad plástica y un nivel de exhibición que no era comparable al de la pintura, reservada a los museos e instituciones artísticas. El estilo de esas imágenes gráficas y publicitarias tendría, a pesar de su fugacidad y supuesta intrascendencia, un efecto profundo en el resto de la producción autónoma del artista, dotando de una nueva sensibilidad a sus pinturas. Por otra parte, las viñetas del diario mostraban una gran capacidad de captar circunstancias históricas complejas pero vistas a través del cristal de la sátira, otorgando así una dimensión cómica, pero no simplificadora, a la descripción de los hechos más incomprensibles de la política y la sociedad de la segunda posguerra.

\section{Referencias}

Belini, C. (2013). “Peronismo, nacionalizaciones y sociedades mixtas. El fracaso de la Empresa Mixta Telefónica Argentina, 1946-1948", en Revista de Historia Iberoamericana, 2 [En línea, https://ri.conicet. gov.ar/bitstream/handle/11336/26553/BeliniRHIB. pdf?sequence=1\&isAllowed=y], DOI 10.3232/RHI.2013. V6.N2.01, última revisión, 15 de marzo de 2020.

Borrini, A. (1984 [1980]). Publicidad: el quinto poder. Buenos Aires: El Cronista Comercial.

Fantoni, G. (1997). Una mirada sobre el arte y la política. Conversaciones con Juan Grela. Rosario: Homo Sapiens Ediciones.

Fisac Seco., J. (1999). La caricatura política en la Guerra Fría: 1946-1963. Catálogo de Exposición. Valencia: Collegi Major Rector Peset, Universitat de Valencia.

García Sebastiani., M. (Ed.) (2006). Fascismo y antifascismo. Peronismo y antiperonismo. Conflictos políticos e ideológicos en la Argentina (1930-1955). Vervuet: Iberoamericana. 
Giunta, A. (1999). "Nacionales y populares: los salones del peronismo", en Penhos, Marta y Wechsler, Diana (Coords.) (1999). Tras los pasos de la norma. Salones Nacionales de Bellas Artes (1911-1989). Buenos Aires: Ediciones del Jilguero, pp. 153-190.

Gociol, J. y Rosemberg, D. (2015). Historia del humor gráfico en Argentina. Lleida: Editorial Milenio.

Lanciotti, N. S. (2008). “Inversiones, transferencia tecnológica y rentabilidad de las empresas extranjeras de electricidad en Argentina. La Sociedad de Electricidad de Rosario, 1910-1956", en Anuario IEHS, 23, 89-117.

Liernur, J. F. y Silvestri, G. (1993). “El torbellino de la electrificación. Buenos Aires, 1880-1930", en El umbral de la metrópolis. Transformaciones técnicas y cultura en la modernización de Buenos Aires (1870-1930). Buenos Aires: Sudamericana, pp. 9-95.

McMahon, R. J., (2009 [2003]). La Guerra Fría, una breve introducción. Madrid: Alianza.

Nállim, J. A., (2014). "Representaciones: la "Nova Lex Perónica", arte deshumanizado y dictadores histéricos", en Las raíces del antiperonismo. Orígenes históricos e ideológicos. Buenos Aires: Capital Intelectual, pp. 195-243.

Palacio, J. (1993). Crónica del humor político en Argentina. Buenos Aires: Editorial Sudamericana.

Sarlo, B. (2004 [1992]). La imaginación técnica. Sueños modernos de la cultura argentina. Buenos Aires: Nueva Visión.
Sueiro Seoane., S. (2007). Posguerra, publicidad y propaganda [1939-1959]. Catálogo de Exposición. Madrid: Círculo de Bellas Artes.

Vázquez Lucio., O. E. (1985). Historia del humor gráfico y escrito en la Argentina. Tomos I y II. Buenos Aires: Eudeba.

Veliscek, E., (2016/2017). “Panteón de los héroes. Retratos de próceres e imaginario nacionalista en el Círculo de la Prensa de Rosario", en Avances. Revista de Artes 26, 291-303.

(2019a). "Humor, política y cultura impresa: la revista Monos y Monadas de Rosario". Documento de trabajo.

(2019b). “La Asociación Amigos del Arte de Rosario: salones, exposiciones e itinerarios de una institución moderna (1944-1959)", en Separata 24, 1-49.

\section{Fuentes}

Diario Crónica, (1945-1947), Rosario, Argentina.

Diario El Orden (1947), Santa Fe, Argentina, 12 de abril.

Montes i Bradley, Ricardo (1947). Tablero plástico.

Boletín de Cultura intelectual. Rosario, enero-junio, p. 33.

Primer Salón del Trabajo. Pintura, dibujo y grabado (1947), cat. exp., Ministerio de Trabajo y Economía, Museo Municipal de Bellas Artes de Santa Fe, 30 de abril al 17 de mayo. 